ABDI: Jurnal Pengabdian dan Pemberdayaan Masyarakat ISSN: 2656-369X (Print), 2684-8570 (Online)

Volume 3 No. 2, Desember 2021

http://abdi.ppj.unp.ac.id/index.php/abdi

Email: abdi@ppj.unp.ac.id

DOI: https://doi.org/10.24036/abdi.v3i2.61

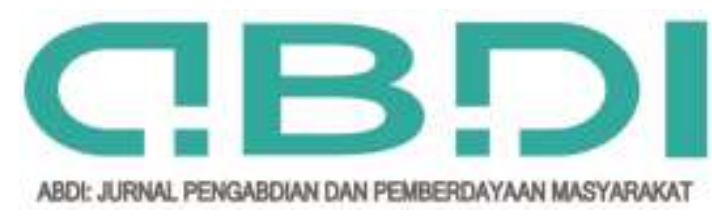

\title{
Menumbuhkembangkan Budaya Literasi Anak Asuh Panti Asuhan Al-Hidayah Kota Padang Melalui Pendampingan dengan Menggunakan Pendekatan Pedagogi
}

\author{
Khairul Fahmi ${ }^{1}$, Nora Susilawati ${ }^{2}$, Rahimullaily Rahimullaily ${ }^{3}$ \\ ${ }^{1,2}$ Jurusan Sosiologi, Universitas Negeri Padang \\ ${ }^{3}$ Prodi Sistem Informasi, STMIK Indonesia Padang
}

E-mail: khairul_fahmi@fis.unp.ac.id, norasusilawati@fis.unp.ac.id, rahimullaily@ stmikindonesia.ac.id

\begin{abstract}
Abstrak
PKM Menumbuhkembangkan budaya literasi anak asuh Panti Asuhan, dilaksanakan di Panti Asuhan AlHidayah Padang. Permasalahan utama yang dihadapi mitra (1) Kurangnya kesadaran dan motivasi anak asuh terhadap membaca buku teks (literasi baca) dan memahami pelajaran di bidang numerik (literasi Numerasi); (2) Belum memadai sarana dan prasarana penunjang budaya literasi di panti asuhan. Dengan permasalahan tersebut solusi yang ditawarkan adalah (1) Meningkatkan kesadaran dan motivasi anak asuh dalam budaya literasi melalui pendampingan dan pembinaan terhadap anak asuh; (2) Peningkatan jumlah dan ragam sumber bacaan bermutu melalui pengoptimalan sumber belajar/ buku bacaan yang tersedia di panti asuhan; (3) Optimalisasi sarana literasi dan perluasan akses terhadap sumber bacaan melaui penciptaan kenyamanan ruang baca/ belajar panti asuhan dan pemanfaatan akses internet yang tersedia di panti asuhan untuk menjangkau bahan bacaan penunjang. Hasil dari kegiatan pengabdian ini adalah (1) Meningkatnya kesadaran dan motivasi anak asuh dalam budaya literasi; (2)Terlaksananya pendampingan dan pembinaan terhadap anak asuh dalam menumbuhkembangkan budaya literasi; (3)Teroptimalkan sumber belajar yang tersedia di perpustakaan panti asuhan; (4) Penambahan jumlah dan ragam sumber bacaan bermutu; (5) Terciptanya kenyamanan ruang belajar/ ruang baca; (6) Termanfaatkan akses internet yang tersedia di panti asuhan untuk menjangkau bahan bacaan penunjang. Target luaran tersebut akan dicapai dengan menggunakan metode pembinaan melalui pemberian materi dan pelatihan. Pendekatan yang digunakan adalah pendekatan pedagogi karena objek dari kegiatan ini adalah anak-anak. Keberlanjutan dari PKM ini adalah, Kemitraan Panti Asuhan Al-hidayah dengan Jurusan Sosiologi UNP dalam bidang literasi.
\end{abstract}

Kata Kunci: Literasi, Panti asuhan, Pedagogi.

Abstract

PKM Develops literacy culture for children in orphanage, held at the Al-Hidayah Padang Orphanage. The main problems faced by partners: (1) Lack of awareness and motivation of foster children towards reading textbooks (reading literacy) and the lack of ability of foster children to understand lessons in the numerical field (Numeration literacy); (2) Inadequate facilities and infrastructure to support literacy culture in the orphanage. With these problems the solutions offered are (1) Increasing awareness and motivation of foster children in a literacy culture through mentoring and coaching foster children; (2) Increasing the number and variety of quality reading sources through optimizing available learning resources books; (3) Optimizing literacy facilities and expanding access to reading sources through the creation of comfortable reading / learning rooms at the orphanage and utilizing internet access available at the orphanage to reach supporting reading materials. The output from this service activity are (1) Increased awareness and motivation of foster children in literacy culture; (2) The implementation of assistance and guidance for foster children in fostering a culture of literacy; (3) Optimized learning resources available in the orphanage library; (4) Increasing the number and variety of quality reading sources; (5) Creating a comfortable study / reading room; (6) Internet access available at the orphanage is utilized to reach supporting reading materials. The output target will be achieved by using coaching methods through the provision of materials and training. The approach used is a pedagogical approach because the objects of this activity are children. The continuation of this PKM is the Al-Hidayah Orphanage Partnership with the Department of Sociology UNP in the field of literacy.

Keyword: Literacy, Orphanages, Pedagogy.

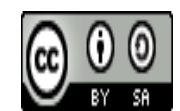

Received: 7 Oktober 2020 Revised: 26 Agustus 2021 Available Online: 27 Agustus 2021 
Khairul fahmi, Nora Susilawati, Rahimullaily Rahimullaily Menumbuhkembangkan Budaya Literasi Anak Asuh Panti Asuhan Al-Hidayah Kota Padang Melalui Pendampingan dengan Menggunakan Pendekatan Pedagogi

\section{Pendahuluan}

Pada saat ini masalah anak yatim, anak piatu, anak yatim piatu dan anak terlantar sudah menjadi fenomena sosial dalam masyarakat kita. Sudah semestinya hal ini mendapat perhatian dari masyarakat dan pemerintah, dimana jumlahnya pun relatif banyak tersebar di perkotaan dan di pedesaan. Sehingga diperlukan penanganan khusus dalam mengelola keberadaan anak yatim, anak piatu, anak yatim piatu dan anak terlantar tersebut. Salah satu upaya pemerintah dan masyarakat dalam rangka penanganan masalah tersebut adalah dengan cara mendirikan panti asuhan. Hal ini sesuai dengan konsep Parents Partial, bahwa bila pengasuhan orang tua (Parental Care) atau keluarga inti kurang atau tidak ada, maka yang bertanggungjawab untuk menjamin kondisi yang memungkinkan anak tumbuh kembang secara baik dan wajar (Sumarnonugroho, 1991). Selain itu pendirian panti asuhan merupakan amanat yang tertuang dalam UUD 1945 pasal 34 yang berbunyi "Fakir miskin dan anak terlantar dipelihara oleh Negara". Pasal ini merupakan usaha proteksi terhadap pihak-pihak tertentu dimana pihak-pihak tertentu tersebut dapat diidentifikasikan sebagai pihak yang bermasalah dan memerlukan pelayan khusus dari Negara, salah satunya melalui panti asuhan.

Panti asuhan merupakan tempat atau asrama untuk memberikan bantuan berupa pemeliharaan dan pendidikan kepada anak-anak yang terlantar dan terganggu perkembangan pribadinya (Suparlan.Y.B, Rachmanto Widjopranoto, 1983). Sedangkan menurut Departemen Sosial, selain istilah panti asuhan juga bisa dipakai panti sosial yaitu suatu institusi atau lembaga baik yang dikelola oleh masyarakat atau pemerintah yang menyelenggarakan pelayanan sosial bagi penyandang masalah kesejahteraan sosial dengan mengasramakan kliennya (anak asuh) (Departemen Sosial, 2005).

Panti asuhan di Kota Padang berjumlah 31 panti yang tersebar pada berbagai kecamatan. Salah satunya adalah Panti Asuhan Al-Hidayah yang beralamat di Jl. Terpadu Kapuk Kel.Kalumbuk Kec. Kuranji Kota Padang. Panti asuhan ini di bawah naungan Yayasan Al-Hidayah Tingkat I Propinsi Sumatera Barat diresmikan pada tanggal 15 Maret 1991 oleh Gubernur Sumatera Barat saat itu (Drs. H. Hasan Basri Durin). Sampai saat ini panti asuhan telah menghasilkan ratusan alumni yang telah bekerja di berbagai daerah di Indonesia.

Berdasarkan data yang didapatkan dari Panti Asuhan Al-Hidayah menunjukkan bahwa jumlah anak asuh saat ini sebanyak 45 orang. Dari 45 orang anak asuh yang terdaftar, panti hanya bisa menempatkan 33 anak asuh laki-laki di dalam asrama panti karena keterbatasan bangunan, saat ini baru ada asrama khusus bagi anak asuh laki-laki. Sedangkan 12 anak asuh lainnya merupakan anak asuh perempuan masing-masing bertempat tinggal di rumah orang tua atau keluarga mereka di sekitar panti. Meskipun demikian, 12 anak asuh tersebut mendapatkan pelayanan yang sama dengan anak asuh di dalam asrama panti. Tingkat pendidikan anak asuh juga beragam mulai dari SD sampai perguruan tinggi. Status sosial anak asuh berbeda, terdiri dari anak yatim, piatu, yatim piatu dan miskin. Rekap data anak asuh Panti Asuhan Al-Hidayah tahun 2020 ditunjukkan pada Gambar 1.

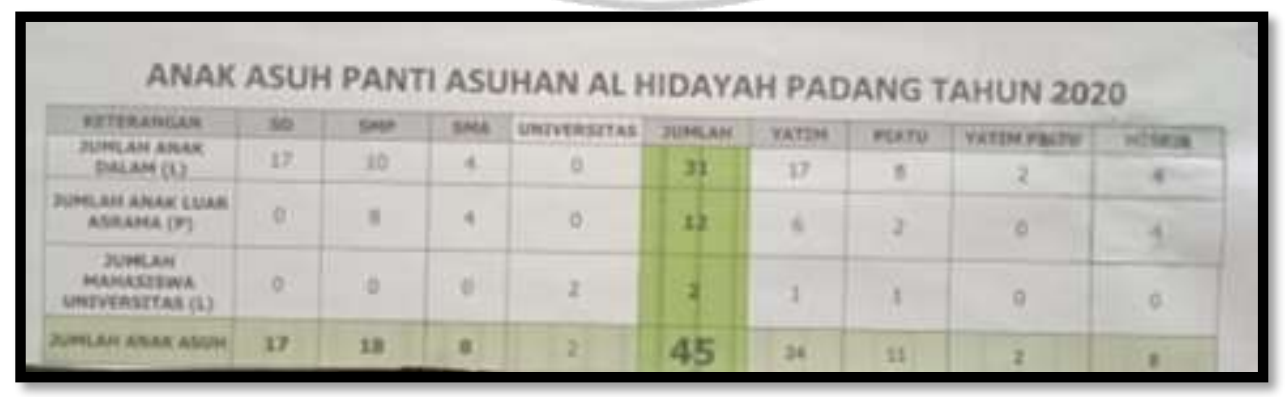

Gambar 1. Rekap Data Anak Asuh Panti Asuhan Al-Hidayah Tahun 2020

Luas bangunan panti asuhan $\pm 2750 \mathrm{~m}^{2}$. Sarana yang dimiliki antara seperti kantor sekretariat, ruang ibadah, ruang belajar/ keterampilan, ruang makan, ruang aula, ruang MCK, dapur, ruang pengasuh, gudang, ruang komputer, ruang tamu, dan lapangan olah raga. Sarana - sarana yang ada masih dalam kondisi terbatas. Dalam hal biaya operasional, untuk menjalankan program kerja, biaya 
Khairul fahmi, Nora Susilawati, Rahimullaily Rahimullaily Menumbuhkembangkan Budaya Literasi Anak Asuh Panti Asuhan Al-Hidayah Kota Padang Melalui Pendampingan dengan Menggunakan Pendekatan Pedagogi

operasional panti asuhan sebagian besar bergantung kepada sumbangan dari pada donatur. Namun panti asuhan juga menciptakan usaha ekonomi produktif untuk menambah pemasukan dan menambah keterampilan anak asuh dalam ekonomi. Beberapa kegiatan usaha ekonomi produktif yang dijalankan adalah usaha ternak ikan, berkebun dan budidaya sayur hidroponik.

Bentuk program kerja panti asuhan meliputi peningkatan pemenuhan kebutuhan dan pelayanan kesejahteraan anak asuh, pemberian pendidikan dan keterampilan bagi anak asuh, meningkatkan prestasi anak asuh dalam segala bidang, meningkatkan pembenahan administrasi yang transparansi dan akuntabilitas, meningkatkan sosialitas program panti kepada masyarakat, dan pengembangan potensi anak asuh. Program kerja utama panti asuhan adalah memberikan pelayanan kepada anak asuh agar anak asuh terpenuhi hak hidup mereka dan anak asuh memiliki kecakapan pengetahuan dan keterampilan. Namun program kerja tersebut belum maksimal dilaksanakan oleh panti karena keterbatasan dana panti, sarana dan prasarana yang dimiliki panti, dan keterbatasan tenaga profesional dalam pembinaan anak asuh.

Dari hasil wawancara tim dengan pengasuh Bapak Untung Widodo Saputro, tergambar bahwa dengan kondisi keterbatasan yang ada saat ini, terutama sarana (seperti kenyamanan ruang baca/ belajar, ketersediaan buku bacaan) dan tenaga profesional, mengakibatkan pengurus panti asuhan belum memiliki program literasi kepada anak asuh. Selama ini pembinaan terhadap anak asuh hanya dilakukan secara konvensional (mengawasi anak asuh belajar dan memandu anak asuh mengerjakan pekerjaan rumah). Kondisi sarana dan prasarana yang ada di panti asuhan belum dimanfaatkan secara optimal sehingga keberadaan sarana dan prasarana tersebut kurang dirasakan manfaatnya untuk menunjang peningkatan kapasitas dan prestasi anak. Beberapa persoalan mendasar terhadap kemampuan anak asuh dalam literasi antara lain, kurangnya minat anak asuh terhadap membaca buku teks (literasi baca) dan kurangnya kemampuan anak asuh dalam memahami pelajaran di bidang numerik (literasi numerasi). Mereka lebih tertarik kepada kegiatan yang bersifat visual (menonton TV). Kondisi ini ditunjukkan dengan masih banyak anak asuh yang memiliki prestasi belajar yang kurang baik.

Kondisi literasi anak asuh tersebut diatas, sejalan dengan hasil survei yang dilakukan oleh International Education Achievement (IEA) pada awal tahun 2000 menunjukkan bahwa kualitas membaca anak-anak Indonesia menduduki urutan ke 29 dari 31 negara yang diteliti di Asia, Afrika, Eropa dan Amerika. Dengan demikian tidaklah mengherankan bila Indeks kualitas sumber daya manusia indonesia masih rendah dibandingkan negara-negara tetangga seperti Malaysia atau Thailand serta Singapura (Rohman, 2017).

Para penggiat pendidikan sepakat bahwa pintu gerbang penguasaan ilmu pengetahuan adalah dengan banyak membaca. Sebab dengan membaca dapat membuka jendela dunia. Ketika jendela dunia sudah terbuka, masyarakat akan dapat melihat keluar, sisi-sisi apa yang ada dibalik jendela tersebut. Sehingga cara berpikir masyarakat kita akan maju dan keluar dari zona kemiskinan menuju kehidupan yang sejahtera (Permatasari, 2015).

Menurut National Institut for Literacy literasi adalah seperangkat kemampuan dan keterampilan individu dalam membaca, menulis, berbicara, menghitung dan memecahkan masalah pada tingkat keahlian tertentu yang diperlukan dalam kehidupan sehari-hari (Ibnu Aji Setyawan, 2018). Sementara dimensi literasi dapat dibedakan menjadi: Literasi Baca dan Tulis, Literasi Numerasi, Literasi Sains, Literasi Digital, Literasi Finansial, dan Literasi Budaya dan Kewargaan. Literasi baca dan tulis adalah pengetahuan dan kecakapan untuk membaca, menulis, mencari, menelusuri, mengolah, dan memahami informasi untuk menganalisis, menanggapi, dan menggunakan teks tertulis untuk mencapai tujuan, mengembangkan pemahaman dan potensi, serta untuk berpartisipasi di lingkungan sosial. Literasi numerasi adalah pengetahuan dan kecakapan untuk (1) bisa memperoleh, menginterpretasikan, menggunakan, dan mengomunikasikan berbagai macam angka dan simbol matematika untuk memecahkan masalah praktis dalam berbagai macam konteks kehidupan sehari-hari; (2) bisa menganalisis informasi yang ditampilkan dalam berbagai bentuk (grafik, tabel, bagan, dsb.) untuk mengambil keputusan.

Literasi sains adalah pengetahuan dan kecakapan ilmiah untuk mampu mengidentifikasi pertanyaan, memperoleh pengetahuan baru, menjelaskan fenomena ilmiah, serta mengambil simpulan 
berdasarkan fakta, memahami karakteristik sains, membangun kesadaran bagaimana sains dan teknologi membentuk lingkungan alam, intelektual dan budaya, serta meningkatkan kemauan untuk terlibat dan peduli dalam isu-isu yang terkait sains.

Literasi digital adalah pengetahuan dan kecakapan untuk menggunakan media digital, alat-alat komunikasi, atau jaringan dalam menemukan, mengevaluasi, menggunakan, membuat informasi, dan memanfaatkannya secara sehat, bijak, cerdas, cermat, tepat, dan patuh hukum dalam rangka membina komunikasi dan interaksi dalam kehidupan sehari-hari. Literasi finansial adalah pengetahuan dan kecakapan untuk mengaplikasikan (1) pemahaman tentang konsep dan risiko, (2) keterampilan, dan (3) motivasi dan pemahaman agar dapat membuat keputusan yang efektif dalam konteks finansial untuk meningkatkan kesejahteraan finansial, baik individu maupun sosial, dan dapat berpartisipasi dalam lingkungan masyarakat. Literasi budaya adalah pengetahuan dan kecakapan dalam memahami dan bersikap terhadap kebudayaan Indonesia sebagai identitas bangsa. Sementara itu, literasi kewargaan adalah pengetahuan dan kecakapan dalam memahami hak dan kewajiban sebagai warga masyarakat. (Kementerian Pendidikan Kebudayaan, 2017).

Dari 6 dimensi literasi di atas, dimensi literasi baca dan literasi numerasi yang menjadi masalah utama persoalan literasi pada Program Kemitraan Masyarakat (PKM) di Panti Asuhan Al-Hidayah. Sehingga diharapkan dengan berjalannya program PKM menumbuhkembangkan budaya literasi anak asuh Panti Asuhan Al-Hidayah ini akan berkontribusi terhadap peningkatan kesadaran dan motivasi anak asuh dalam budaya literasi yang pada akhirnya akan bermuara dalam peningkatan prestasi anak asuh di sekolah.

Berdasarkan analisis situasi, dapat dinyatakan bahwa belum adanya kegiatan penumbuhkembangan budaya literasi untuk anak asuh panti asuhan Al-Hidayah. Sehingga anak asuh belum terbiasa dengan aktivitas literasi yang akan menunjang kepada peningkatan kapasitas dan prestasi belajar mereka. Kondisi ini karena keterbatasan sarana prasarana penunjang serta kenyamanan dalam kegiatan literasi anak asuh dan kurangnya tenaga profesional yang mampu menciptakan budaya literasi anak asuh. Sarana dan prasarana yang masih kurang tersebut adalah kondisi ruang belajar yang belum memberikan kenyamanan bagi anak dan belum tersedianya buku-buku yang penunjang yang memadai. Oleh karena itu, hal yang menjadi permasalahan dalam PKM ini adalah: (1) Kurangnya kesadaran dan motivasi anak asuh terhadap membaca buku teks (literasi baca) dan kurangnya kemampuan anak asuh dalam memahami pelajaran di bidang matematika (literasi numerasi). (2) Belum memadai sarana dan prasarana penunjang budaya literasi di panti asuhan (kenyamanan ruang belajar dan ketersediaan buku penunjang).

\section{Metode Pelaksanaan}

\subsection{Strategi dan Langkah Pelaksanaan}

Strategi langkah-langkah yang ditempuh untuk menjalankan solusi atas permasalahan yang dihadapi oleh mitra adalah:

\subsubsection{Peningkatan kesadaran dan motivasi dalam budaya literasi}

Langkah strategi: Melakukan pendampingan dan pembinaan terhadap anak asuh untuk menumbuhkembangkan budaya literasi (literasi baca dan numerasi) melalui pemberian materi dan pelatihan.

\subsubsection{Peningkatan jumlah dan ragam sumber bacaan bermutu}

Langkah strategi: Pengoptimalan sumber belajar/ buku bacaan yang tersedia di panti asuhan agar dapat dimanfaatkan anak asuh dan Penambahan koleksi bahan bacaan dengan berbagai jenis tema di perpustakaan panti asuhan.

\subsubsection{Optimalisasi sarana literasi dan perluasan akses terhadap sumber bacaan.}


Khairul fahmi, Nora Susilawati, Rahimullaily Rahimullaily Menumbuhkembangkan Budaya Literasi Anak Asuh Panti Asuhan Al-Hidayah Kota Padang Melalui Pendampingan dengan Menggunakan Pendekatan Pedagogi

Langkah strategi: Menciptakan kenyamanan ruang baca/ belajar panti asuhan dan Pemanfaatan akses internet yang tersedia di panti asuhan untuk menjangkau bahan bacaan penunjang.

Strategi dan langkah-langkah pelaksanaan kegiatan di atas diawali dengan konsolidasi tim dan sosialisasi program kepada mitra kemudian diakhiri dengan evaluasi pelaksanaan kegiatan untuk menilai ketercapaian target luaran.

\subsection{Metode Pendekatan}

Metode yang digunakan dalam pelaksanaan kegiatan ini adalah metode pendampingan. Metode pendampingan ini memiliki prinsip yang dikenal dengan istilah "Nobody has nothing". Setiap manusia terlahir dengan kelebihan masing-masing. Tidak ada yang tidak memiliki potensi, walau hanya sekedar kemampuan untuk tersenyum dan memasak air. Semua berpotensi dan semua bisa berkontribusi. Dengan demikian, tidak ada alasan bagi setiap manusia untuk tidak berkontribusi nyata terhadap perubahan lebih baik. Bahkan, keterbatasan fisik pun tidak menjadi alasan untuk tidak berkontribusi (Dureau, 2013).

Pendekatan yang digunakan adalah pendekatan pedagogi karena objek dari kegiatan ini adalah anak-anak. Pendekatan pedagogi menurut Sudarwan Danim merupakan ilmu dan seni antara lain yaitu:

1. Pengajaran (teaching) yaitu teknik dan metode kerja guru dalam mentransformasikan konten pengetahuan, merangsang mengawasi dan memfasilitasi pengembangan siswa untuk mencapai tujuan pembelajaran, pengertian ini menempatkan guru pada posisi sentral.

2. Belajar (learning) yaitu proses siswa mengembangkan kemandirian dan inisiatif dalam memperoleh dan meningkatkan pengetahuan serta keterampilan.

3. Hubungan mengajar dengan belajar dengan segala faktor lain yang ikut mendorong minat pedagogi. Hubungan ini bisa bermakna siswa dibimbing guru atau kegiatan belajar yang berpusat pada siswa, namun tetap di bawah bimbingan guru.

4. Hubungan mengajar dan belajar berkaitan dengan semua pengaturan dan pada segala tahapan usia, sebagaimana dikembangkan di lembaga pendidikan formal dan nonformal (Hiryanto, 2017) Dalam implementasi metode pendekatan yang digunakan, partisipasi mitra sangat menjadi penentu keberhasilan kegiatan. Partisispasi mitra dalam kegiatan ini adalah mitra berperan aktif sebagai peserta dalam setiap proses pembinaan yang dilakukan. Selain itu mitra juga berkontribusi dalam penyediaan ruangan pelatihan, penyediaan fasilitas laptop/ komputer serta penyediaan jaringan internet untuk pembelajaran.

\section{Hasil dan Pembahasan}

Kegiatan PKM menumbuhkembangkan budaya literasi anak asuh panti asuhan Al hidayah telah berjalan sesuai dengan perencanaan yang yang telah disiapkan. Setelah tim PKM melakukan diskusi untuk implementasi kegiatan PKM maka disepakatilah strategi pelaksanaan kegiatan. Pada tahap awal pelaksanaan kegiatan PKM ini, diawali dengan sosialisasi program kepada pengurus dan seluruh anak asuh panti asuhan $\mathrm{Al}$ hidayah. Kegiatan sosialisasi ini bertujuan untuk menyampaikan rencana program PKM, tujuan dan sasaran program serta tahapan kegiatan yang akan dilalui. Kegiatan sosialisasi ini telah dilaksanakan pada bulan Agustus 2020 dihadiri oleh pengurus panti asuhan, anak asuh dan tim PKM. Berikut dokumentasi pelaksanaan sosialisasi kegiatan.

Setelah sosialisasi PKM dilakukan, semua stakeholder panti asuhan dan tim PKM memahami tujuan dan maksud dari kegiatan PKM. Harapannya semua stakeholder mendukung kegiatan PKM ini. Pada tahapan selanjutnya tim PKM melaksanakan implementasi kegiatan menumbuhkembangkan budaya literasi anak asuh di panti asuhan al hidayah. Berikut adalah hasil kegiatan PKM menumbuhkembangkan budaya literasi anak asuh panti asuhan Al hidayah: 


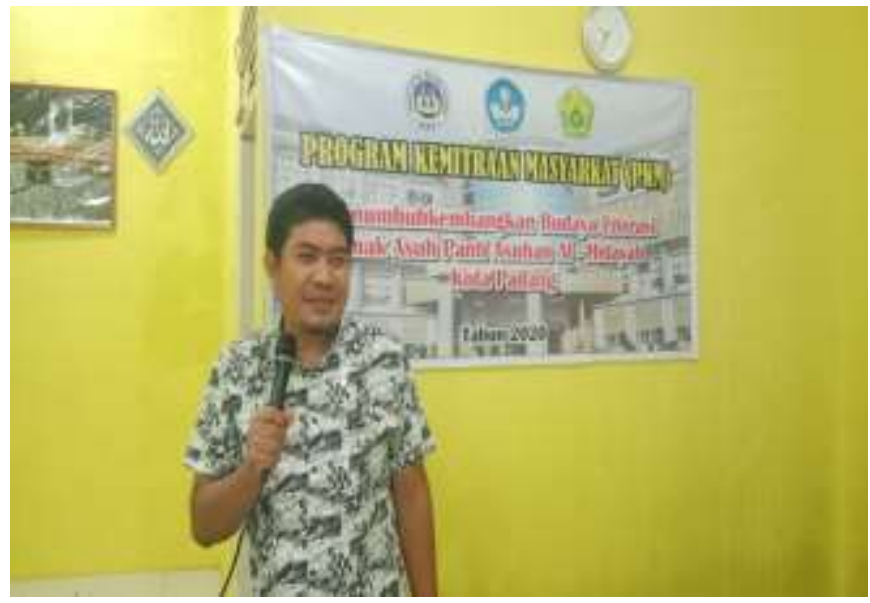

Gambar 2. Sosialisasi Kegiatan PKM

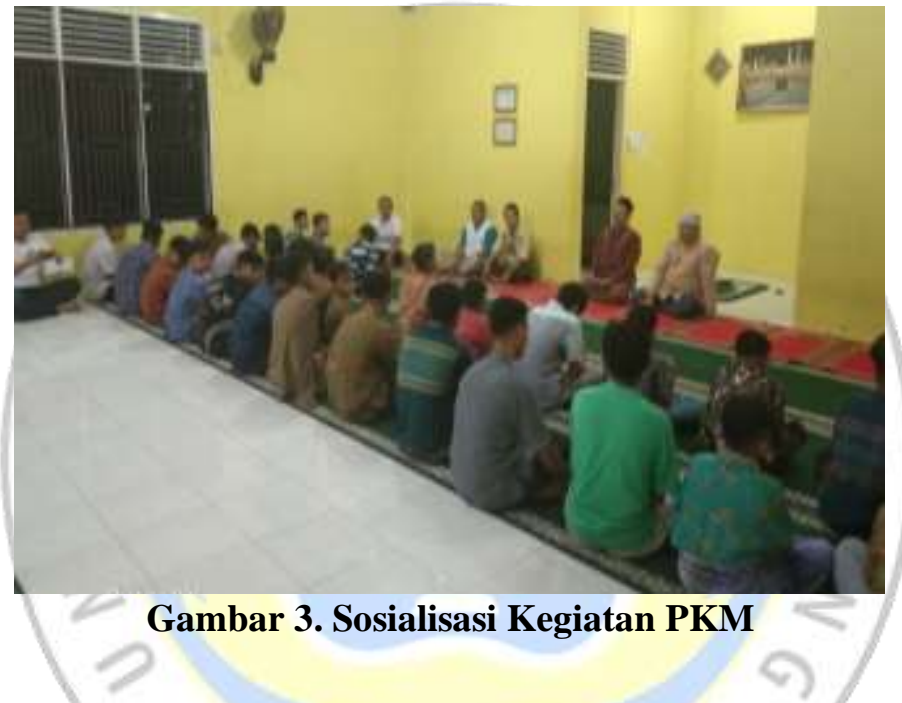

\subsection{Meningkatnya kesadaran dan motivasi dalam budaya literasi melalui pendampingan dan pembinaan terhadap anak asuh dalam menumbuhkembangkan budaya literasi}

Pada tahapan ini dilakukan beberapa kegiatan motivasi melalui ceramah interaktif untuk meningkatkan kesadaran dan semangat anak asuh dalam budaya literasi. Tim PKM memberikan motivasi langsung kepada anak asuh dan juga mendatangkan narasumber yang berkompeten untuk meningkatkan kesadaran dan motivasi anak asuh dalam budaya literasi ini. Terutama yang berkaitan dengan literasi numerasi yang menjadi beban bagi banyak anak asuh dalam pembelajaran matematika.

Dari pelaksanaan kegiatan motivasi ini, dapat digambarkan bahwa anak asuh sangat antusias mengikuti karena narasumber memberikan ceramah secara interaktif dan beberapa kali melibatkan anak asuh dengan metode game interaktif

Selain motivasi melalui ceramah interaktif, budaya literasi anak asuh di kembangkan melalui proses pendampingan dilakukan secara berkala dengan menggunakan pendekatan pedagogi. Beberapa metode pedagogi yang diterapkan adalah:

a) Pengajaran (teaching) yaitu teknik dan metode kerja guru dalam mentransformasikan konten pengetahuan, merangsang mengawasi dan memfasilitasi pengembangan siswa untuk mencapai tujuan pembelajaran

b) Belajar (learning) yaitu proses siswa mengembangkan kemandirian dan inisiatif dalam memperoleh dan meningkatkan pengetahuan serta keterampilan. 
Khairul fahmi, Nora Susilawati, Rahimullaily Rahimullaily Menumbuhkembangkan Budaya Literasi Anak Asuh Panti Asuhan Al-Hidayah Kota Padang Melalui Pendampingan dengan Menggunakan Pendekatan Pedagogi

c) Hubungan mengajar dengan belajar dengan segala faktor lain yang ikut mendorong minat pedagogi. Hubungan ini bisa bermakna siswa dibimbing guru atau kegiatan belajar yang berpusat pada siswa, namun tetap di bawah bimbingan guru.

d) Hubungan mengajar dan belajar berkaitan dengan semua pengaturan dan pada segala tahapan usia.

Dalam melakukan kegiatan pendampingan ini, tim membuat pembagian tugas untuk turun kelapangan. Dengan melibatkan mahasiswa, minimal 1 kali dalam dua minggu tim turun kelapangan untuk melakukan pertemuan dan pendampingan kepada anak asuh. Dalam pendampingan tersebut, tim mengajak anak asuh untuk hobi membaca buku. Melalui pendekatan pedagogi anak asuh menikmati proses pendampingan yang diberikan.

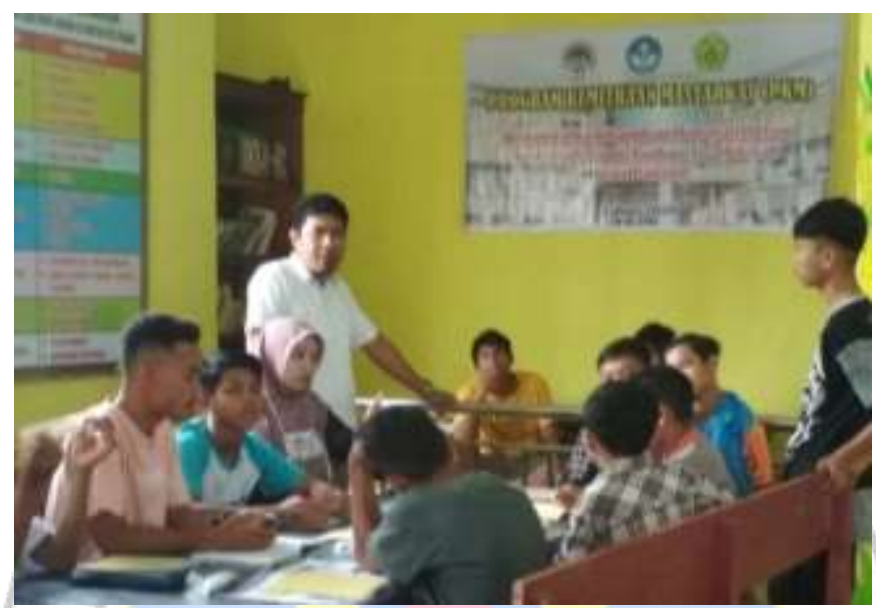

\section{Gambar 4. Tim Melakukan Pendampingan Literasi Kepada Anak Asuh}

\subsection{Optimalisasi sumber belajar/ buku bacaan yang tersedia di perpustakaan panti asuhan}

Pada saat ini panti asuhan sudah memiliki perpustakaan sederhana namun belum tertata dan dikelola dengan baik. Jumlah buku bacaan pun masih kurang tetapi buku-buku yang ada tersebut masih dapat dimanfaatkan sebagai sumber referensi literasi. Pada tahapan ini anak asuh didorong untuk memanfaatkan buku-buku bacaan dan buku ajar yang telah ada di panti asuhan dengan cara memfilter dan mengelompokkan sumber-sumber bacaan yang sudah tersedia di panti asuhan.

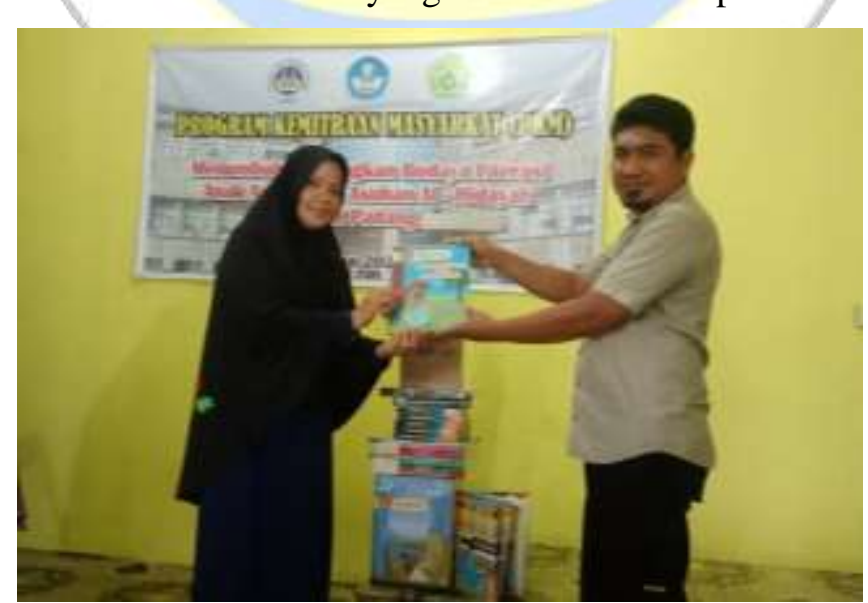

Gambar 5. Penyerahan Bantuan Koleksi Buku Untuk Pustaka Panti Asuhan 
Khairul fahmi, Nora Susilawati, Rahimullaily Rahimullaily Menumbuhkembangkan Budaya Literasi Anak Asuh Panti Asuhan Al-Hidayah Kota Padang Melalui Pendampingan dengan Menggunakan Pendekatan Pedagogi

\subsection{Penambahan jumlah dan ragam sumber bacaan bermutu}

Pada tahapan ini, sesuai dengan perencanaan yang telah disiapkan, diberikan paket penambahan buku bacaan baru yang terdiri dari buku cerita, biografi tokoh dan buku-buku penunjang pendidikan karakter. Ada 37 judul buku yang di serahkan ke panti asuhan. Penambahan buku-buku bacaan baru ini tentunya menambah koleksi buku di perpustakaan panti asuhan dan menambah motivasi anak asuh dalam literasi.

\subsection{Terciptanya kenyamanan ruang belajar/ baca (dekorasi ruang belajar/ baca)}

Pada tahapan ini dilakukan kegiatan pembersihan, pengecatan dan merapikan pustaka panti asuhan. Dalam kegiatan ini anak asuh ikut berpartisipasi dalam menciptakan suasana bersih dan nyaman di ruang baca. Anak asuh ikut membersihkan ruang baca, Menyusun buku sesuai tema. Untuk pengecatan ruangan, diserahkan kepada tukang professional sehingga ruangan terlihat lebih bersih dan nyaman untuk digunakan.

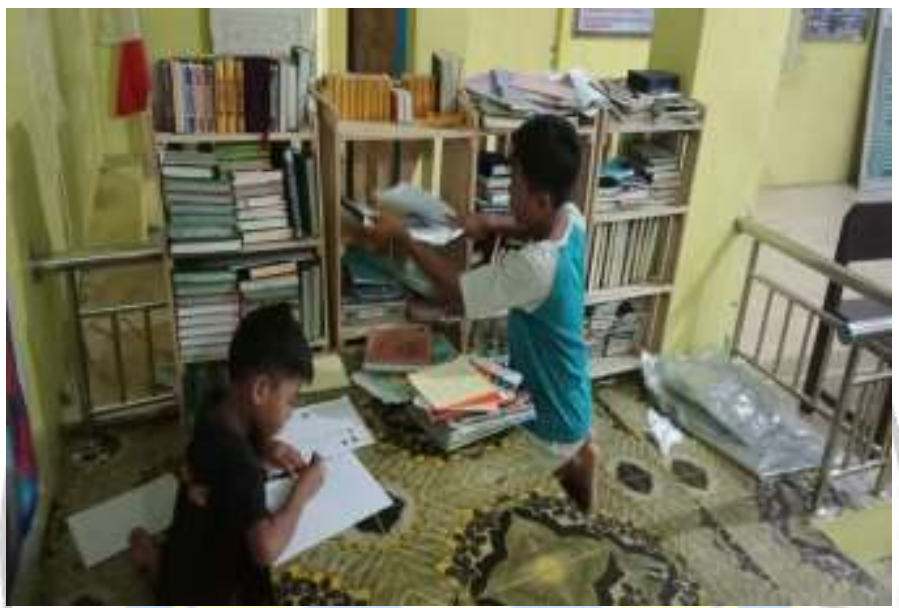

Gambar 6. Menciptakan Kenyamanan Ruang Belajar

3.5. Termanfaatkan akses internet yang tersedia di panti asuhan untuk menjangkau bahan bacaan penunjang.

Pada saat ini di panti asuhan telah tersedia jaringan internet sebagai penunjang belajar anak asuh terutama saat pembelajaran daring. Ketersediaan jaringan internet tersebut sangat potensial untuk mengakses literasi digital dari internet sekaligus untuk menjadikan anak asuh cerdas menggunakan internet. Pada tahapan ini, anak asuh di ajarkan menemukan sumber-sumber terpercaya penunjang pengetahuan melalui akses internet yang tersedia di panti asuhan.

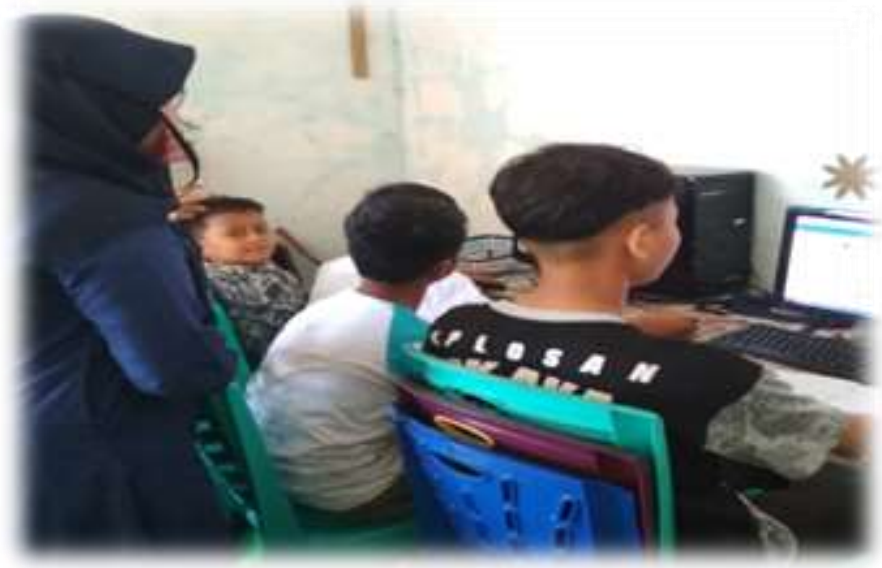

Gambar 7. Pemanfaatan Akses Internet Untuk Literasi 
Khairul fahmi, Nora Susilawati, Rahimullaily Rahimullaily Menumbuhkembangkan Budaya Literasi Anak Asuh Panti Asuhan Al-Hidayah Kota Padang Melalui Pendampingan dengan Menggunakan Pendekatan Pedagogi

\section{Kesimpulan}

Program PKM Menumbuhkembangkan Budaya Literasi Anak Asuh Panti Asuhan Al-Hidayah Kota Padang dapat dilaksanakan sesuai dengan tahapan dan waktu yang telah direncanakan. Dengan menggunakan metode pendampingan melalui pendekatan pedagogi telah didapatkan pencapaian dari kegiatan PKM ini adalah:

1. Meningkatnya kesadaran dan motivasi anak asuh dalam budaya literasi melalui pendampingan dan pembinaan terhadap anak asuh dalam menumbuhkembangkan budaya literasi.

2. Teroptimalkan sumber belajar/ buku bacaan yang tersedia di perpustakaan panti asuhan.

3. Penambahan jumlah dan ragam sumber bacaan bermutu sebanyak 37 judul buku

4. Terciptanya kenyamanan ruang belajar/ baca.

5. Termanfaatkan akses internet yang tersedia di panti asuhan untuk menjangkau bahan bacaan penunjang.

Evaluasi pelaksanaan kegiatan PKM ini dapat dianalisis dari aspek kognitif, afektif, dan psikomotorik peserta pembinaan. Aspek kognitif dilihat dari pemahaman dari peserta pembinaan, afektif dilihat dari semangat dan minat peserta dalam mengikuti pembinaan dan aspek psikomotorik dilihat dari kemampuan peserta dalam mengimplementasikan materi yang telah didapatkan. Untuk memastikan keberlanjutan program, dilakukan dengan cara mendorong pengurus terutama pengasuh untuk terus megembangkan budaya literasi yang telah tumbuh kembang pada anak asuh. Selain itu Panti Asuhan Al hidayah diusulkan kepada Jurusan Sosiologi UNP sebagai lembaga binaan Jurusan Sosiologi UNP melalui kerjasama antar lembaga.

\section{Daftar Pustaka}

Departemen Sosial. (2005). Petunjuk Pelaksanaan Subsidi Tambahan Biaya Permakanan. Jakarta: Departemen Sosial RI.

Dureau, C. (2013). Pembaru dan kekuatan lokal untuk pembangunan, Australian Community Development and Civil Society Strengthening Scheme (ACCESS) Tahap II.

Hiryanto, H. (2017). Pedagogi, Andragogi dan Heutagogi Serta Implikasinya Dalam Pemberdayaan Masyarakat. Dinamika Pendidikan, 22, 65-71.

Ibnu Aji Setyawan, S. P. (2018). Kupas Tuntas Jenis dan Pengertian Literasi. http://gurudigital.id/jenispengertian-literasi-adalah/

Kementerian Pendidikan Kebudayaan. (2017). Panduan Gerakan Literasi Nasional. Jakarta: Kementerian Pendidikan Kebudayaan.

Permatasari, A. (2015). Membangun Kualitas Bangsa dengan Budaya Literasi. Seminar Nasional Bulan Bahasa UNIB, 146-156.

Rohman, S. (2017). Membangun Budaya Membaca Pada Anak Melalui Program Gerakan Literasi Sekolah. Jurnal Pendidikan Dan Pembelajaran Dasar, 4(1), 156.

Sumarnonugroho, T. (1991). Sistem Intervensi Kesejahteraan Sosial (3rd ed.). Yogyakarta: Hanindita Graha Widya.

Suparlan.Y.B, Rachmanto Widjopranoto, S. P. (1983). Kamus istilah kesejahteraan sosial. Yogkarta: Pustaka Pengarang. 